\title{
Pengaruh Sistem Penghargaan (Reward) Terhadap Kinerja Trainee Di Hotel Holiday Inn Resort Baruna Bali
}

\author{
Putu Panca Adi Pratiwi Indah, Putu Indah Rahmawati, Nyoman Dini Andiani \\ Undiksha
}

\begin{abstract}
Abstrak
Penelitian ini bertujuan untuk mengetahui pengaruh sistem penghargaan (reward) terhadap kinerja trainee di Holiday Inn Resort Baruna Bali. Objek penelitian adalah Holiday Inn Resort Baruna Bali. Populasi penelitian ini adalah trainee disemua departement dan sampel penelitian adalah tiga puluh orang trainee dari semua departement di Hotel Holiday Inn Resort Baruna Bali. Penelitian ini menggunakan teknik deskriptif kuantitatif yang di dapatkan dengan kuesioner dengan skala likert diolah menggunakan sistem spss, kemudian hasil yang didapatkan dari mengolah data akan di deskripsikan dengan sistematis. Hasil penelitian ini menunjukkan bahwa adanya pengaruh yang siginifikan sistem penghargaan (reward) terhadap kinerja trainee. Hal ini dapat dilihat dimana trainee yang diberikan apresisasi atau reward menunjukkan kinerja yang lebih baik dari pada trainee yang tidak diberikan penghargaan (reward). Jadi dapat disimpulkan bahwa sistem pemberian reward kepada trainee memiliki efek yang positif terhadap kinerja trainee.
\end{abstract}

Kata Kunci: Sistem Penghargaan, Reward, Kinerja, Trainee, Hotel

\begin{abstract}
This study aimed at investigating the effect of reward system towards trainee's performance in Holiday Inn Resort Baruna Bali. The object of this study was Holiday Inn Resort Baruna Bali. The population of this study was the all trainee of department and sample of this study was thirty of trainee in Holiday Inn Resort Baruna Bali. This study uses descriptive quantitative techniques obtained by questionnaire with likert scale will then be processed using spss system, then the results obtained from the data processing described systematically. It was found that there is a significant effect of of reward system towards trainee's performance in Holiday Inn Resort Baruna Bali. It can be seen that the performance of trainee who given any reward was increased. So it can be concluded that reward system has a positive effect towards trainee's performance.
\end{abstract}

Key Word: Reward System, Reward, Performance, Trainee, Hotel

\section{Pendahuluan}

Di era moderenisasi ini, persaingan dunia usaha semakin tinggi terlebih lagi pada dunia pariwisata khususnya perhotelan. Ragam usaha dipersaingkan dan kualitas kinerja traineepun ditinggikan guna pencapaian target usaha yang diinginkan. Sumber Daya Manusia (SDM) merupakan faktor sentral dalam pengelolaan suatu organisasi. Dalam mencapai tujuannya, suatu organisasi 
memerlukan Sumber Daya Manusia (SDM) sebagai pengelola sistem. Sumber Daya Manusia (SDM) yang kompeten dengan kinerja yang baik, dapat menunjang keberhasilan bisnis. Sebaliknya Sumber Daya Manusia (SDM) yang tidak kompeten dan kinerjanya buruk merupakan masalah kompetitif yang dapat menempatkan perusahaan dalam kondisi yang merugi.

Kinerja dalam organisasi merupakan jawaban dari berhasil atau tidaknya tujuan organisasi yang telah ditetapkan. Kinerja seorang trainee merupakan hal yang bersifat individual, karena setiap trainee mempunyai tingkat kemampuan yang berbeda-beda dalam mengerjakan tugasnya. Rendahnya tingkat kinerja trainee dapat menimbulkan dampak negatif bagi perusahaan seperti malas bekerja, kurangnya prestasi kerja, dan disiplin trainee. Hal ini bukan semata mata diakibatkan oleh trainee itu sendiri, tetapi perlu diperhatikan faktor - faktor seperti bagaimana kondisi kerja trainee dalam memenuhi tuntutan kerja perusahaan, peraturan yang ditetapkan oleh perusahaan, sehingga tercipta kondisi demikian. Kinerja trainee dapat ditingkatkan dengan memberikan contoh yang baik dari seorang pemimpin, memotivasi trainee dan selalu memperhatikan trainee dalam bekerja.

Sebagai proses, kepemimpinan difokuskan kepada apa yang dilakukan oleh para pemimpin, yaitu proses di mana para pemimpin menggunakan pengaruhnya untuk memperjelas tujuan organisasi bagi para trainee, bawahan, atau yang dipimpinnya, memotivasi mereka untuk mencapai tujuan tersebut. Penting bagi pemimpin untuk mempertimbangkan kualitas kinerja Sumber Daya Manusianya, salah satunya ialah pengakuan tingkat ketepatan dan kecepatan trainee dalam bentuk penghargaan (reward). Dengan adanya sistem ini hasil kerja yang digarap oleh trainee menjadi lebih ternilai.

Program penghargaan penting bagi organisasi karena mencerminkan upaya organisasi untuk mempertahankan SDM sebagai komponen utama dan merupakan komponen biaya yang paling penting. Disamping pertimbangan tersebut, penghargaan juga merupakan salah satu aspek yang berarti, karena bagi individu atau trainee besarnya penghargaan mencerminkan ukuran nilai karya mereka diantara para trainee itu sendiri, keluarga, dan masyarakat (Sulistiyani dan Rosidah, 2003).

Berdasarkan gambaran umum tentang reward salah satu Hotel yang terletak di kawasan strategis kawasan Kuta, Bali yaitu Holiday Inn Resort Baruna ini dikenal sebagai salah satu hotel berbintang 5 berada dibawah 
Intercontinental Hotel Group, menerapkan penghargaan The Best Trainee bagi trainee yang berprestasi setiap 3 bulan sekali. Sistem reward yang diterapkan dalam perusahaan ini mempertimbangkan kinerja traineenya yang harus sesuai dengan standar dari perusahaan sehingga reward bisa diberikan dan diharapkan untuk dapat memotivasi semua trainee untuk meningkatkan kinerjanya.

Berdasarkan latar belakang tersebut diatas maka penulis menemukan rumusan masalah sebagai berikut: (1) Apa saja jenis reward di Holiday Inn Resort Baruna Bali?; (2) Apakah reward berpengaruh terhadap kinerja trainee?; (3) Strategi untuk meningkatkan kinerja dengan sistem reward?

\section{Kajian Pustaka}

\subsection{Konsep Reward}

Reward merupakan salah satu elemen yang dapat digunakan atau dimanfaatkan oleh suatu organisasi untuk memotivasi trainee agar dapat memberikan kontribusi yang lebih maksimal. Dalam konteks ini reward itu sendiri memiliki makna yang luas dan tidak hanya terfokus pada financial saja. Thompson (2002) menekankan bahwa reward tidak hanya mencakup unsur kuantitatif seperti gaji, upah dan lain lain, tetapi juga unsur lainnya yang berwujud bukan uang, seperti kesempatan untuk melaksanakan tanggung jawab yang lebih besar, peluang karir, kesempatan untuk belajar dan berkembang, kualitas kehidupan yang layak dalam organisasi dan lain-lain. Menurut Puwanethiren (2011) reward itu terbentuk dari seluruh komponen organisasi, proses, aturan serta kegiatan pengambilan keputusan dalam hal alokasi untuk memberikan kompensasi dan manfaat kepada karyawan sebagai timbal balik atas kontribusi yang telah diberikan kepada organisasi.

Reward dapat pula didefinisikan sebagai salah satu tindakan timbal balik yang diberikan oleh suatu organisasi atau pimpinan kepada karyawan/trainee ketika mereka telah dianggap mampu melakukan tindakan atau tugas yang diberikan organisasi secara tepat dan cepat (Rahim \& Daud, 2012).

Besar kecilnya reward yang diberikan kepada yang berhak bergantung kepada banyak hal, terutama ditentukan oleh tingkat pencapaian yang diraih. Selain itu bentuk reward ditentukan pula oleh jenis atau wujud pencapaian yang diraih serta kepada siapa reward tersebut diberikan.

\subsection{Konsep Kinerja}


Kinerja dapat diartikan sebagai suatu hasil yang telah dicapai oleh seseorang dalam dunia kerja yang mana bisa kita dapat melalui tugas dan tanggung jawab yang diberikan. Pada dasarnya suatu perusahaan bukan saja mengharapkan seorang trainee yang memiliki kecakapan yang baik dan terampil tetapi yang terpenting mereka mau bekerja dan berkeinginan untuk mencapai hasil kerja yang optimal. Kinerja pula dapat diartikan sebagai sebuah prestasi kerja yang merupakan hasil dari implementasi rencana kerja yang dibuat oleh suatu institusi yang dilaksanakan oleh pimpinan dan Sumber Daya Manusia (SDM) yang bekerja di institusi itu baik pemerintah maupun perusahaan (bisnis) untuk mencapai tujuan organisasi (Abdullah 2014: 3).

Kinerja yang dicapai karyawan/trainee dianggap mampu memberikan kontribusi terhadap keberhasilan perusahaan secara keseluruhan. Apabila perusahaan mempunyai Sumber Daya Manusia (SDM) yang berkualitas maka kinerja yang dicapai perusahaan juga akan semakin meningkat. Dalam pelaksanaannya perusahaan memerlukan informasi tentang kinerja karyawan/trainee. Informasi tersebut bermanfaat untuk beberapa keperluan, misalnya untuk peningkatkan gaji, kebutuhan promosi, mutasi atau untuk melakukan pengendalian atas penyimpangan-penyimpangan yang mungkin terjadi.

\subsection{Konsep Pengaruh Reward terhadap Kinerja}

Menurut Mulyadi (2001) sistem reward dan pengakuan atas kinerja trainee merupakan sarana untuk mengarahkan perilaku trainee keperilaku yang dihargai dan diakui oleh organisasi. Dengan pemberian reward yang telah ditetapkan organisasi, bagaimana dukungan seseorang dalam menghadapi pekerjaan akan melihat bagaimana dampak pemberian reward kepada seseorang sesuai dengan yang ditetapkan organisasi, dan bagaimana dampak pemberian reward yang telah ditetapkan organisasi, memperkuat atau memperlemah hubunganya dengan kinerja.

Reward atau penghargaan dapat menjadi suatu alat bagi perusahaan dalam memecahkan masalah yang berhubungan dengan pengelolaan trainee dan merupakan salah satu alat untuk memotivasi trainee. Jika orang merasakan bahwa terdapat kemungkinan yang tinggi suatu kinerja yang baik akan mendapatkan penghargaan (reward) yang diterima didasarkan atas kinerja yang baik, motivasi orang berusaha mencapai sasaran yang telah ditetapkan akan tinggi. Begitu juga sebaliknya, jika terdapat kemungkinan yang rendah suatu 
kinerja memperoleh reward, maka motivasi orang untuk mencapai sasaran yang telah ditetapkan akan rendah pula.

\subsection{Konsep Strategi Meningkatkan Kinerja}

Dalam memberikan suatu penghargaan atau yang kerap kita kenal dengan sebutan reward tidaklah asal memberikan saja kepada setiap trainee yang ada pada lingkungan sebuah organisasi, akan tetapi sudah tentu pengendali strategi manajemen memiliki sebuah strategi pengukuran kinerja setiap para trainee dalam memberikan sebuah reward sehingga nantinya bisa meningkatkan kinerja mereka. Seperti halnya segala sesuatu yang diberikan organisasi untuk memuaskan satu atau beberapa kebutuhan individu disebut sebagai penghargaan atau reward. Dengan strategi inilah nantinya seorang pemimpin perusahaan atau organisasi mampu meningkatkan kinerja para trainee. Reward yang dimaksud dalam konteks ini dapat digolongkan ke dalam dua kelompok (Mulyadi, 2007) yaitu:

1) Reward Instrinsik (non-financial) Berupa rasa puas diri yang diperoleh seseorang yang telah berhasil menyelesaikan pekerjaannya dengan baik dan telah mencapai sasaran tertentu.

2) Reward Ekstrinsik (financial). Reward ekstrinsik sendiri terdiri dari kompensasi yang diberikan kepada trainee, baik yang berupa: a. Kompensasi langsung maupun kompensasi tidak langsng.

Penelitian terkait judul ini telah dilakukan oleh beberapa peneliti terdahulu yaitu: Wijayanti dan Prabbu (2016) "Pengaruh Penghargaan dan Motivasi Terhadap Kinerja Karyawan"; Fadilla (2009) "Pengaruh Sistem Penghargaan terhadap Kinerja Karyawan Bank Danamon Cabang Utama Medan “. Terdapat beberapa persamaan dan perbedaan antara penelitian ini dibandingkan dengan penelitian-penelitian terdahulu. Adapun persamaanya adalah sama-sama menggunakan teknik analisis data deskriptif kuantitatif yang mana data yang didapatkan lebih banyak dari kuesioner, selain itu penelitian ini dan penelitian terdahulu meneliti mengenai pengaruh reward terhadap kinerja. Adapun perbedaannya adalah dari segi jumlah responden, subjek dan objek penelitian serta teknik sampling yang digunakan dalam pengambilan data, penelitian di atas menggunakan non random sample dengan metode purposive sampling sedangkan penelitian ini menggunakan non random sample dengan metode accidental sampling yang mana sistem penghargaan (reward) sebagai variabel $(\mathrm{X})$ dan kinerja trainee sebagai variabel $(\mathrm{Y})$. Nantinya dalam penelitian ini akan 
didapat dua kemungkinan yaitu $\mathrm{HO}$ : pemberian reward tidak memiliki pengaruh terhadap kinerja trainee atau kemungkinan $\mathrm{H} 1$ : pemberian reward memiliki pengaruh yang signifikan terhadap kinerja trainee.

\section{Metode Penelitian}

\subsection{Lokasi Penelitian}

Lokasi penelitian ini dilakukan di Holiday Inn Baruna Resort, Bali yang bertempat dikawasan Kuta tepatnya di Jalan Wanasegara no. 33 Tuban, Bali.

\subsection{Populasi dan Sampel}

Populasi penelitian ini adalah semua trainee di semua department Holiday Inn Resort Baruna, Bali.

\subsection{Metode Pengumpulan Data}

Teknik pengumpulan data yang digunakan dalam penelitian ini adalah dokumentasi dan kuisioner. Angket dalam penelitian ini diukur dengan menggunakan skala pengukuran likert dengan alternatif jawaban sangat setuju diberi skor lima, setuju diberi skor empat, netral diberi skor tiga, tidak setuju diberi skor dua dan sangat tidak setuju diberi skor satu.

\subsection{Teknik Analisis Data}

Penelitian ini menggunakan teknik penelitian kuantitatif yang terdiri atas distribusi frekuensi, uji normalitas, uji heteroskedatisitas, uji autokorelasi, analisi regresi linear sederhana dan uji hipotesis $(\mathrm{t})$ dengan bantuan software Statistical Package for Social Science (SPSS) 21

\section{Hasil Penelitian dan Pembahasan}

Dalam penelitian ini pengumpulan data dilakukan dalam satu tahapan yakni dengan cara penyebaran kuisioner kepada responden yaitu trainee di Holiday Inn Resort Baruna Bali yang berjumlah 30 responden. Berdasarkan hasil analisis deskriptif dapat digambarkan bahwa dari 30 orang responden pada penelitian ini kebanyakan berjenis kelamin Laki-Laki yaitu 17 orang $(56,67 \%)$ dan Perempuan 13 orang $(43,33 \%)$. Responden tersebut terdidi dari berbagai departemen yaitu bagian Housekeeping 6 orang (20\%), bagian $F \& B$ 
Service 6 orang (20\%), bagian Kitchen 6 orang (20\%), bagian Front Office 6 orang (20\%), dan bagian Manajemen 6 orang (20\%).

Data yang telah diperoleh dianalisis dengan menggunakan analisis statistik deskriptif digunakan untuk mengetahui gambaran responden yang menjadi subjek penelitian melalui frekuensi dan variasi jawaban reponden terhadap item/ butir pernyataan terhadap kuesioner yang telah disebarkan. Hasil angket tersebut meliputi variabel Sistem Penghargaan (X) dan Variabel Kinerja (Y). Uji penelitian ini bermaksud untuk mengetahui adanya pengaruh antara variabel bebas (Sistem Penghargaan) terhadap variabel terikat (Kinerja) secara langsung maupun tidak langsung.

\section{Uji Normalitas}

Hipotesis :

$\mathrm{H}_{0 \text { : }}$ Residual data berdistribusi normal $(>0,05)$

$\mathrm{H}_{1}$ : Residual data tidak berdistribusi normal $(<0,05)$

Dengan $\alpha=5 \%=0,05$

Kriteria Uji: Tolak $\mathrm{H}_{0}<0,05$

Dengan SPSS dihasilkan output sebagai berikut.

\section{One-Sample Kolmogorov-Smirnov Test}

\begin{tabular}{|ll|l|}
\hline & & $\begin{array}{l}\text { Unstandardize } \\
\text { d Residual }\end{array}$ \\
\hline $\mathrm{N}$ & & 30 \\
Normal & Mean & .0000000 \\
Parameters ${ }^{\mathrm{a}, \mathrm{b}}$ & Std. Deviation & 2.47916236 \\
& Absolute & .137 \\
Most Extreme & Positive & .137 \\
Differences & Negative & -.062 \\
& Kolmogorov-Smirnov Z & .750 \\
Asymp. Sig. (2-tailed) & .627 \\
\hline
\end{tabular}

a. Test distribution is Normal.

b. Calculated from data.

Terima $\mathrm{H}_{0}$ (karena $0,627>0.05$ ). Didapatkan bahwa residual data berdistribusi normal. 


\section{Heteroskedastisitas}

Hipotesis :

$\mathrm{H}_{0}$ : Tidak ada gejala heteroskedastisitas. (Sig $\left.>0,05\right)$

$\mathrm{H}_{1}$ : Ada gejala heteroskedastisitas. $(\mathrm{Sig}<0,05)$

Kriteria Uji: Tolak $\mathrm{H}_{0}<0,05$

Dengan SPSS dihasilkan output sebagai berikut.

\section{Coefficients $^{\mathrm{a}}$}

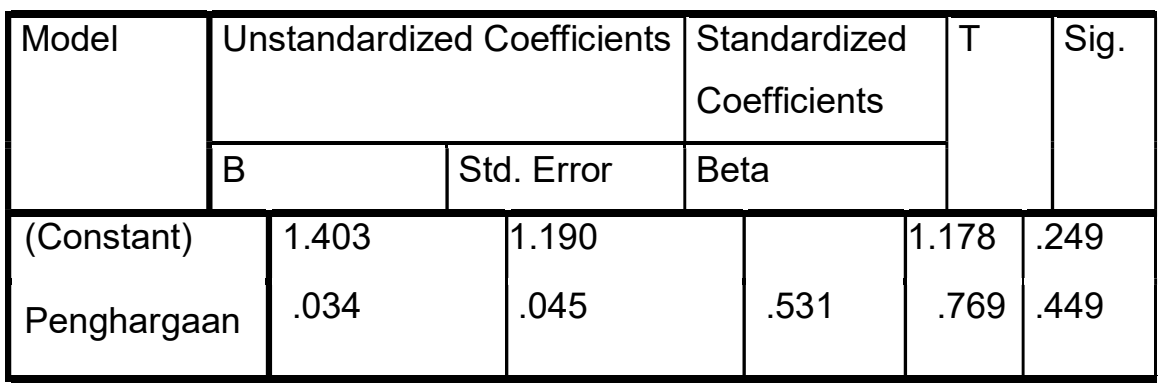

a. Dependent Variable: RES2

Terima $\mathrm{H}_{0}$ karena signifikan $0,449>0,05$. Artinya tidak ada gejala heteroskedastisitas, yang mana residualnya memiliki ragam atau varian yang sama/homogen.

\section{Auto korelasi}

Model Summary ${ }^{b}$

\begin{tabular}{|l|r|r|r|r|r|}
\hline Model & $\mathrm{R}$ & R Square & $\begin{array}{c}\text { Adjusted R } \\
\text { Square }\end{array}$ & $\begin{array}{c}\text { Std. Error } \\
\text { of the } \\
\text { Estimate }\end{array}$ & Durbin- \\
Watson \\
\hline 1 & $.667^{\mathrm{a}}$ & .445 & .425 & 2.52304 & 2.234 \\
\hline
\end{tabular}

a. Predictors: (Constant), penghargaan

b. Dependent Variable: kinerja

Untuk $\mathrm{n}=30$ didapat:

1. Jika d lebih kecil dari $\mathrm{dL}$ atau lebih besar dari (4-dL) maka hipotesis nol ditolak, yang berarti terdapat autokolerasi.

2. Jika d terletak antara dU dan (4-dU), maka hipotesis nol diterima, yang berarti tidak ada autokorelasi. 
Karena nilai Durbin-Watson yang didapatkan berada pada interval di atas, yaitu 2,234 maka dikatakan bahwa dalam model regresi linear tidak terjadi autokorelasi.

\section{Uji Linearitas}

Hipotesis :

$H_{0}$ : Variabel $X$ dan $Y$ memiliki hubungan linear.

$\mathrm{H}_{1}$ : Variabel $\mathrm{X}$ dan $\mathrm{Y}$ tidak memiliki hubungan linear.

Dengan $\alpha=5 \%=0,05$

Kriteria Uji : Tolak $\mathrm{H}_{0}>0,05$

Dengan SPSS dihasilkan output sebagai berikut.

ANOVA $^{a}$

\begin{tabular}{|l|l|l|l|l|l|}
\hline Model & $\begin{array}{l}\text { Sum of } \\
\text { Squares }\end{array}$ & Df & $\begin{array}{l}\text { Mean } \\
\text { Square }\end{array}$ & F & Sig. \\
\hline Regression & 11.317 & 1 & 11.317 & 7.662 & $.010^{\mathrm{b}}$ \\
Residual & 41.358 & 28 & 1.477 & & \\
Total & 52.674 & 29 & & & \\
\hline
\end{tabular}

a. Dependent Variable: RES2

b. Predictors: (Constant), Penghargaan

Terima $\mathrm{H}_{0}(0,010<0,05)$. Artinya variabel $X$ dan $Y$ memiliki hubungan yang linear. Sehingga asumsi uji regresi linear sederhana terpenuhi.

\section{Uji Hipotesis (Uji t)}

Hipotesis:

$\mathrm{H}_{0}$ : Tidak ada pengaruh yang nyata (signifikan) variabel $X$ (Penghargaan) terhadap variabel $\mathrm{Y}$ (Kinerja Trainee).

$\mathrm{H}_{1}$ : Ada pengaruh yang nyata (signifikan) variabel $\mathrm{X}$ (Penghargaan) terhadap variabel $\mathrm{Y}$ (Kinerja Trainee).

Dengan $\alpha=5 \%=0,05$

Kriteria Uji : Tolak $\mathrm{H}_{0}<0,05$ 
Dengan SPSS dihasilkan output sebagai berikut.

\section{Coefficients $^{\mathrm{a}}$}

\begin{tabular}{|c|c|c|c|c|c|}
\hline \multirow[t]{2}{*}{ Model } & \multicolumn{2}{|c|}{$\begin{array}{c}\text { Unstandardized } \\
\text { Coefficients }\end{array}$} & \multirow{2}{*}{$\begin{array}{c}\text { Standardize } \\
\text { d } \\
\text { Coefficients } \\
\text { Beta }\end{array}$} & \multirow[t]{2}{*}{$\mathrm{T}$} & \multirow[t]{2}{*}{ Sig. } \\
\hline & $B$ & Std. Error & & & \\
\hline (Constant) & 7.326 & 5.224 & & 1.402 & .172 \\
\hline Penghargaan & .787 & .166 & .667 & 4.735 & .000 \\
\hline
\end{tabular}

Dependen variabel : Kinerja

Dari output di atas dapat diketahui nilai t hitung $=4,735$ dengan nilai signifikan $0,000<0,05$, maka $\mathrm{H} 0$ ditolak dan $\mathrm{H} 1$ diterima, yang berarti ada pengaruh nyata (signifikan) ) variabel $X$ (Sistem Penghargaan) terhadap variabel $Y$ (Kinerja Trainee). Serta didapatkan $\beta_{0}=7,326$ dan $\beta_{1}=0,787$ maka persamaannya regresi linear sederhananya, yaitu : $Y=7,326+$ $0,787 X$.

\section{Pembahasan}

Dalam konteks ini, reward itu sendiri memiliki makna yang luas dan tidak hanya terfokus pada financial saja. Reward tidak hanya mencakup unsur kuantitatif seperti gaji, upah dan lain-lain, tetapi juga unsur lainnya yang berwujud bukan uang (non-financial), seperti kesempatan untuk melaksanakan tanggung jawab yang lebih besar, peluang karir, kesempatan untuk belajar dan berkembang, kualitas kehidupan yang layak dalam organisasi dan lain-lain. Reward yang dimaksud dalam konteks ini dapat digolongkan ke dalam dua kelompok (Mulyadi, 2007) yaitu: Reward instrinsik (non-financial) dan reward ekstrinsik (financial). Dalam hal ini, Hotel Holiday Inn Resort Baruna Bali memberikan reward instrinsik berupa sertifikat atau penghargaan berupa ucapan terimakasih dari pimpinan perusahaan kepada trainee atas kesuksesan kerja yang dicapai. Sedangakan reward ekstrinsik berupa bonus langsung maupun tidak langsung berupa hero card, yang mana dari point tersebut dapat ditukar dengan barang sesuai dengan besar kecilnya point. 
Dari hasil uji hipotesis di atas didapatkan nilai t hitung yaitu 4,735 yang mana nilai signifikannya 0,000 atau $<0,05$ yang menyatakan bahwa variabel bebas yaitu teknik penghargaan $(\mathrm{X})$ memiliki pengaruh yang signifikan terhadap variabel terikat yaitu kinerja trainee $(\mathrm{Y})$ yang mana kinerja trainee akan menurun jika mendapatkan pengaruh yang menyimpang dari teknik reward yang diterapkan oleh supervisor/senior, hal ini berbanding terbalik jika senior selalu mengapresiasi kinerja dari trainee maka kinerja trainee akan meningkat. Hal ini didukung dengan penelitian Fadilla (2009) yang mana disebutkan berdasarkan hasil uji t, sistem penghargaan $(\mathrm{X})$ berpengaruh secara positif dan signifikan terhadap kinerja karyawan (Y). Kemudian dilanjutakan oleh Jati (2017) yang juga menemukan bahwa adanya pengaruh yang signifikan antara reward terhadap kinerja karyawan/trainee. Sehingga dapat disimpulkan bahwa semakin tinggi tingkat kemampuan seorang karyawan memaknai serta merasakan adanya manfaat yang mereka terima dari reward tersebut, maka akan semakin meningkatkan pula kualitas kinerja dalam suatu organisasi. Hal ini tentunya akan banyak memberikan nilai positif bagi perusahaan itu sendiri, karena tingkat kualitias Sumber Daya Manusia (SDM) akan memberikan pengaruh yang besar terhadap tingkat keberhasilan suatu perusahaan/organisasi.

Menurut Mulyadi (2001) sistem penghargaan berbasis kinerja merupakan suatu alat pengendalian penting yang digunakan oleh perusahaan untuk memotivasi personil agar mencapai tujuan perusahaan dengan perilaku sesuai dengan yang diharapkan perusahaan. Seperti hasil penilitian yang dilakukan di Holiday Inn yang mana manajemen organisasinya juga menerapkan sistem pemberian penghargaan bagi trainee untuk meningkatkan kualitas kinerja Sumber Daya Manusianya. Berdasarkan kuisioner yang telah diisi, memperlihatkan bahwa pencapian sebuah kuantitas, kualitas serta kemampuan bekerja sama yang baik itu dipengaruhi oleh penghargaan yang diberikan seperti pemberian bonus/hero card, piagam penghargaan atau sertifikat kepada karyawan maupun trainee serta adanya pengakuan dari pemimpin perusahaan yang berupa pujian/ucapan yang sifatnya penyampaian terima kasih atas kesuksesan kerja yang dicapai oleh karyawan maupun trainee. Hal ini sangat mempengaruhi psikologis dari karyawan maupun trainee tersebut karena apa yang mereka lakukan dengan penuh usahan akhirnya dianggap bernilai positif dari pimpinan tersebut, maka semakin meningkat pula rasa dan keinginannya untuk bekerja dengan makimal. Hasil penelitian diatas didukung oleh pernyataan 
yang mana segala sesuatu yang diberikan organisasi untuk memuaskan satu atau beberapa kebutuhan individu itu disebut sebagai penghargaan atau reward. Dengan strategi inilah seorang pemimpin perusahaan atau organisasi mampu meningkatkan kinerja para trainee.

\section{Penutup}

Berdasarkan analisis dan pembahasan tentang pengaruh Sistem Penghargaan terhadap kinerja trainee di Holiday Inn Resort Baruna, maka dapat disimpulkan sebagai berikut:

1. Reward merupakan salah satu elemen yang dapat digunakan atau dimanfaatkan oleh suatu organisasi untuk memotivasi trainee agar dapat memberikan kontribusi yang lebih maksimal. Dalam konteks ini reward itu sendiri memiliki makna yang luas dan tidak hanya terfokus pada financial saja tetapi juga termasuk non-financial.

2. Pemberian reward memiliki pengaruh yang kuat terhadap tingkat kinerja trainee, hal tersebut dapat dibuktikan dengan analisa uji $\mathrm{t}$ (hipotesis) dimana didapatkan nilai $t$ hitung yaitu sebesar 4,735 dengan nilai signifikannya $0,000<0,05$ yang menyatakan bahwa variabel bebas yaitu teknik penghargaan $(X)$ memiliki pengaruh signifikan terhadap variabel terikat yaitu kinerja trainee $(\mathrm{Y})$.

3. Seperti hasil penelitian yang dilakukan di Holiday Inn yang mana manajemen organisasinya juga menerapkan sistem pemberian penghargaan bagi trainee untuk meningkatkan kualitas kinerja Sumber Daya Manusianya. Berdasarkan kuisioner yang telah diisi, memperlihatkan bahwa pencapian sebuah kuantitas, kualitas serta kemampuan bekerja sama yang baik itu dipengaruhi oleh penghargaan yang diberikan seperti pemberian bonus/hero card, piagam penghargaan atau sertifikat kepada karyawan maupun trainee serta adanya pengakuan dari pemimpin perusahaan yang berupa pujian/ucapan yang sifatnya penyampaian terima kasih atas kesuksesan kerja yang dicapai oleh karyawan maupun trainee 


\section{Daftar Pustaka}

Dharma, Surya. 2004. Manajemen Kinerja, Falsafah, Teori dan Penerapannya. Yogyakarta: Pustaka Pelajar.

Dzulkifli, Muhammad. 2013.Pengaruh Gaya Kepemimpinan, Motivasi, Disiplin kerja, Kompetensi dan Budaya Organisasi terhadap Kinerja Pegawai. Jakarta.

Fadilla, Riski. 2009. Pengaruh Sistem Penghargaan terhadap Kinerja Karyawan Bank Danamon Cabang Utama Medan. Medan, 70. Tersedia pada http://repository.usu.ac.id/bitstream/handle/123456789/11016/09E02703.pd f?sequence=1\&isAllowed $=y$ pada hari Minggu, 7 April 2019.

Hidayat, Faizal. 2018. Pengaruh Reward dan Punishment terhadap Kinerja Karyawan dengan Disiplin Kerja sebagai Variabel Intervening di Waroeng Spesial Sambal Yogyakarta. Yogyakarta.

Irawanti, Arik. 2016. Pengaruh Pemberian Reward dan Punishment terhadap Kinerja Karyawan (Studi Kasus pada Bmt Lima Satu Sejahtera Jepara).Semarang.Diakses

http://eprints.walisongo.ac.id/6276/1/112411096.pdf pada hari Senin, 8 April 2019.

Mangkunegara, AA. Anwar Prabu. 2000. Evaluasi Kinerja SDM, Cetakan Kedua, PT Refika Aditama, Bandung.

Meyrina, Susana Andi. 2017,Mei. Pelaksanaan Reward dan Punishment terhadap Kinerja Pegawai di Lingkungan Kementerian Hukum dan Ham.Jakarta

Selatan.Diakses file:///C:/Users/USER/Downloads/151-984-1-PB.pdf pada hari Sabtu, 6 April 2019.

Mulyadi. 2001. Ekonomi Sumber Daya Manusia Dalam Perspektif Pembangunan, Jakarta: Radja Grafindo Persada.

Panggabean, M. S. 2002. Manajemen Sumber Daya Manusia. Cetakan Pertama. Jakarta: Ghalia Indonesia.

Prabu, Aldila Saga, dkk. 2016. Pengaruh Penghargaan dan Motivasi Terhadap Kinerja Karyawan. Surabaya.

Sugiyono. 2017. Statistika Untuk Penelitian, Cetakan ke 28. Alfabeta. Bandung.

Sulistiyani, Ambar Teguh dan Rosidah. 2003. Manajemen Sumber Daya Manusia. Yogyakarta: Graha IImu.

www.google.com 2019. Peta Hotel Holiday Inn Resort Baruna. Tersedia pada https://www.google.com/maps/place/Holiday+Inn+Resort+Baruna+Bali/@$\underline{8.7373453,115.1612675,17 \mathrm{z} / \mathrm{data}=! 3 \mathrm{~m} 1 ! 4 \mathrm{~b} 1 ! 4 \mathrm{~m} 5 ! 3 \mathrm{~m} 4 ! 1 \mathrm{~s} 0 \times 2 \mathrm{dd} 244204904}$ 
JMPP, Vol 2 No 1, April 2019

p-ISSN: 2654-9719

eb6f:0xf1d1d317f9fbbbcc!8m2!3d-8.7373506!4d115.1634562 diakses pada tanggal 25 April 2019. 